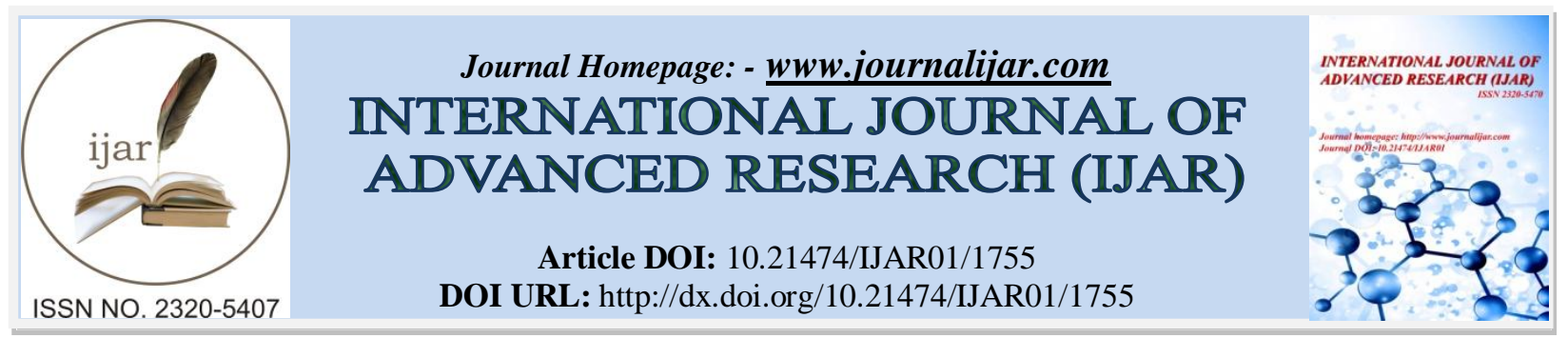

RESEARCH ARTICLE

\title{
EVALUATION OF THE CHEMICAL COMPOSITION OF ESSENTIAL OILS FROM LEAVES OF SUDANESE OCIMUM GRATISSIMUM AND OCIMUM BASILICUM.
}

\section{Itmad Awad Elhassan", Amira Ahmed Hamed-Elneel and Reem Ahmed Adam.}

Pharmaceutical Industries Research Department, Industrial Research and Consultancy Centre, Khartoum, Sudan, P.O Box 268-Khartoum.

\section{Manuscript Info}

Manuscript History

Received: 12 August 2016

Final Accepted: 22 September 2016

Published: October 2016

Key words:-

O. basilicum, O. gratissimum,

chemotype, estragole,

eugenol/caryophellene

\section{Abstract}

The genus Ocimum (Lamiaceae) involves economically the most important medicinal and aromatic herbs and comprises more than 150 species distributed in tropical and subtropical regions. The objective of this research is to investigate the chemical constituents in the essential oils from leaves of $O$. gratissimum and $O$. basilicum grown in Sudan. The essential oils from the leaves were obtained by hydrodistillation method and analyzed by GC-MS. The yield of the hydrodistilled essential oils obtained from leaves of $O$. gratissimum and $O$. basilicum L. were $0.5 \%$ and $0.8 \%$ (v/w) respectively. Twenty four compounds were detected in $O$. gratissimum oil; eugenol $(41.74 \%)$, caryophellene $(21.99 \%)$, isocaryophellene $(12.36 \%)$, piperitone $(3.43 \%)$ and methyl chavicol $(2.74 \%)$ were the major constituent identified. Thirty nine compounds were detected in $O$. basilicum oil; methyl chavicol $(39.26 \%)$, linalool $(17.41 \%)$, 1,8-cineole $(5.75 \%)$ and m-eugenol $(3.51 \%)$ were the major constituent identified. It could be concluded that $O$. gratissimum and $O$. basilicum cultivated in Sudan could be classified as eugenol/caryophellene chemotype and methyl chavicol (estragole) chemotype, respectively.

Copy Right, IJAR, 2016,. All rights reserved.

\section{Introduction:-}

The genus Ocimum (Lamiaceae) involves economically the most important medicinal and aromatic herbs and comprises more than 150 species distributed in tropical and subtropical regions of Asia, Africa and Central and South America (Paton 1992).

It represents an important source of essential oils and aroma compounds used in foods, perfumery and cosmetics industry (Simon et al., 1984; Simon et al., 1990).

The sub-species and varieties in the genus Ocimum vary significantly in their essential oil composition, especially on the main constituents.

Essential oils of $O$. gratissimum (clove basil) and $O$. basilicum (sweet basil) from various origins were investigated by many researchers. The essential oil of O. gratissimum from Brazil contained eugenol (34.6 - 73.1\%) and 1,8cineole (5.6 - 22.6\%) as the main constituents (Silva et al., 2004); that from Colombia contained eugenol (43.2\%),1,8-cineole (12.8\%) and $\beta$-selinene $(9.0 \%) ; \beta$-caryophellene and germacrene-D were also detected in 
considerable amounts (Benitez et al., 2009). Indian O. gratissimum essential oil characterized by presence of eugenol (47.45\%) and citronellal (3.56\%) and lesser amounts of 1,8-cineole, geraniol and vanillin (Saha et al., 2013); that from Kenya characterized by presence of eugenol (68.8\%), methyl eugenol (13.21\%), cis-ocimene (7.47\%), germacrene D (4.25\%), trans-caryophyllene (1.69\%) and traces of other hydrocarbon terpenes (Matasyoh et al., 2007).

Thymol (32.7\%) was found to be the main constituent in $O$. gratissimum essential oil from Nigeria, followed by pcymene $(25.4 \%)$ and $\gamma$-terpinene $(10.8 \%)$ as concluded by Asawalam et al., (2008). O. gratissimum essential oil from Togo contained (Thymol (31.79\%), p-cymene $(15.57 \%)$ and $\gamma$-terpinene $(12.34 \%)$ among twenty six identified components (Koba et al., 2009). Essential oil of $O$. gratissimum from Benin was dominated by p-cymene (28-54 thymol (9-25\%), followed by $\beta$-myrcene and $\alpha$-thujene (Quetin-Leclercq et al., 2012).

On the other hand, essential oil of $O$. basilicum from Thailand characterized by presence of methyl chavicol (estragole) as the dominant constituent (92.48\%) (Bunrathep et al., 2007) whereas that from Iran contained methyl chavicol (52.4\%) and linalool (20.1\%) for the $c v$. Purple; methyl chavicol (40.5\%), geranial (27.6\%) and neral (18.5\%) for the $c v$. green (Sajjids, 2006).

Indonesian $O$. basilicum essential oil was dominated by methyl chavicol $(85 \%)$ and linalool (4\%), followed by linalool and linalool oxide (Mindaryani and Sri Rahayu, 2007); that from Prague composed of methyl chavicol (up to $45 \%$ ), Linalool (15-26\%), eugenol (10-22\%), bergamotene and methyl cinnamate were also detected among the other constituents (Holadova et al. 2008). O. basilicum essential oil from Malaysia contained methyl chavicol (30.87 $-80.95 \%$ ) as the major constituent (Vani et al., 2009).

$O$. basilicum essential oil from Turkey was dominated by methyl eugenol (78.02\%) followed by $\alpha$-cubebene (6.17\%) and traces of other compounds (Ozcan and Chalchat, 2002); that from Pakistan contained linalool (56.7$60.6 \%$ ), epi- $\alpha$-cadinol (8.6-11.4\%), $\alpha$-bergamotene (7.4-9.2\%) as the major constituents (Anwar et al., 2008).

Linalool (69.2\%) was reported to be the main constituent in essential oil of $O$. basilicum from Serbia (BericBjedovet et al., 2007). The oil from China contained linalool (29.68\%) followed by (Z)- cinnamic acid methyl ester (21.49\%) among the detected compounds (Wu et al., 2009).

Geraniol (34.89\%) and citral (23.51\%) were the dominant constituents documented in the essential oil of $O$. basilicum from India (Saha et al., 2013). Linalool (69.87\%) was found to be the major constituent in the essential oil isolated from the aerial parts of O. basilicum grown in Oman (Khan et al., 2015).

Generally, $O$. basilicum oils have been classified according to their geographical source into three large groups which are the European type, the Reunion type and the tropical type. They are also classified as chemotypes based on their major constituents in to, for example, methyl chavicol, methyl cinnamate, methyl eugenol and linalool chemotypes (Lawrence, 1988; Koutsos et al., 2009; Koba et al., 2009; Singh et al., 2014). On the other hand, nine chemotypes were reported for $O$. gratissimum: linalool/methyl chavicol, eugenol/1,8-cineole/sesquiterpenes, methyl cinnamate, methyl-eugenol/eugenol, ethyl cinnamate, citral, geraniol, eugenol and thymol-rich-chemotypes (Brada et al., 2011).

The objective of this research is to investigate the chemical constituents in the essential oils from leaves of $O$. basilicum and $O$. gratissimum grown in Sudan.

\section{Materials and methods:- \\ Plant material:-}

O. basilicum and O. gratissimum leaves werevcollected from the Nursery of the Horticulture Sector Administration, Ministry of Agriculture, Khartoum, Sudan.

\section{Essential oils preparation:-}

The essential oils were obtained from the leaves of $O$. basilicum and $O$. gratissimum by hydro-distillation, using Clevenger apparatus, for four hrs. The yield was expressed in percent of the dry material (v/w). The oil was dried over anhydrous sodium sulfate. 


\section{GC-MS analysis of the oil:-}

The essential oil was analyzed by gas chromatography coupled with mass spectrometry (GCMS-QP 2010). The sample was dissolved in dichloromethane $(1 \%)$ and injected at $250{ }^{\circ} \mathrm{C}$ (Injector temperature) into the capillary column type HP-1, 30m x $0.25 \mathrm{~mm}$ i.d., stationary phase $(95 \%$ diethyl $-5 \%$ diphenylsiloxane, $0.25 \mu \mathrm{m}$ film thickness), using helium as a carrier gas at a flow rate of $1.2 \mathrm{ml} / \mathrm{min}$. The injected volume was $1 \mu \mathrm{l}$ and the injection mode used was split (split ration 50:1). The initial oven temperature was $35^{\circ} \mathrm{C}$ held for $3 \mathrm{~min}$, then raised at a rate of $5{ }^{\circ} \mathrm{C} / \mathrm{min}$ up to $240{ }^{\circ} \mathrm{C}$, then at a rate of $3{ }^{\circ} \mathrm{C} / \mathrm{min}$ up to $280{ }^{\circ} \mathrm{C}$, held for $4 \mathrm{~min}$. Detector temperature was $200{ }^{\circ} \mathrm{C}$. The MS was operated in the El mode at $70 \mathrm{eV}$. The mass and scan range was set at $m / z 35-450$.

\section{Compounds identification:-}

Identification of compounds from the essential oils was achieved by matching their mass spectra with reference spectra from the computer library of NIST or Wiley Registry of Mass Spectral Data.

\section{Results and Discussion:-}

The yield of the hydro-distilled essential oils obtained from leaves of $O$. gratissimum and $O$. basilicum L. were $0.5 \%$ and $0.8 \%(\mathrm{v} / \mathrm{w})$ respectively.

Gas chromatogram of $O$. gratissimum essential oil revealed detection of twenty four compounds. About $99 \%$ of the constituents were identified. The constituents of the essential oil of O. gratissimum, as well as their percentage abundance, are shown in Table (1) according to their retention times.

Table 1:- The chemical composition of the essential oils of $O$. gratissimum.

\begin{tabular}{|c|c|c|c|}
\hline Peak & RT & Compound & percentage \\
\hline 1 & 12.933 & $(+)$-4-carene & 0.24 \\
\hline 2 & 13.082 & n-octanal & 0.43 \\
\hline 3 & 13.903 & Limonene & 0.31 \\
\hline 4 & 13.999 & 1,8 -cineole & 0.22 \\
\hline 5 & 15.275 & 1 -octanol & 0.16 \\
\hline 6 & 16.192 & linalool & 1.60 \\
\hline 7 & 19.233 & Methyl chavicol & 2.74 \\
\hline 8 & 20.882 & Piperitone & 3.43 \\
\hline 9 & 23.908 & Eugenol & 1.74 \\
\hline 10 & 24.440 & Eudesmo-4(14),11-diene & 12.36 \\
\hline 11 & 24.713 & Isocaryophellene & 21.99 \\
\hline 12 & 25.555 & Caryophellene & 2.38 \\
\hline 13 & 26.258 & $\alpha$-humulene & 0.66 \\
\hline 14 & 26.744 & $\gamma$-selinene & 1.87 \\
\hline 15 & 27.071 & $\beta$-selinene & 2.04 \\
\hline 16 & 27.285 & $\alpha$-selinene & 1.84 \\
\hline 17 & 27.553 & $\beta$-elemene & 0.44 \\
\hline 18 & 27.692 & $\gamma$-cadinene & 1.1 \\
\hline 19 & 28.510 & Elemol & 0.86 \\
\hline 20 & 29.403 & Caryophellene oxide & 0.48 \\
\hline 21 & 30.66 & $\Delta$-cadinene & 0.6 \\
\hline 22 & 31.141 & Selina-6-en-4-ol & 0.41 \\
\hline 23 & 46.899 & Unidentified & 0.55 \\
\hline 24 & 49.067 & Unidentified & \\
\hline
\end{tabular}

O. gratissimum essential oil consisted mainly of oxygenated monoterpenes (50.63\%) and hydrocarbon sesquiterpenes $(45.12 \%)$ followed by oxygenated sesquiterpenes $(4 \%)$ and traces of hydrocarbon monoterpenes (Fig. $1)$. 


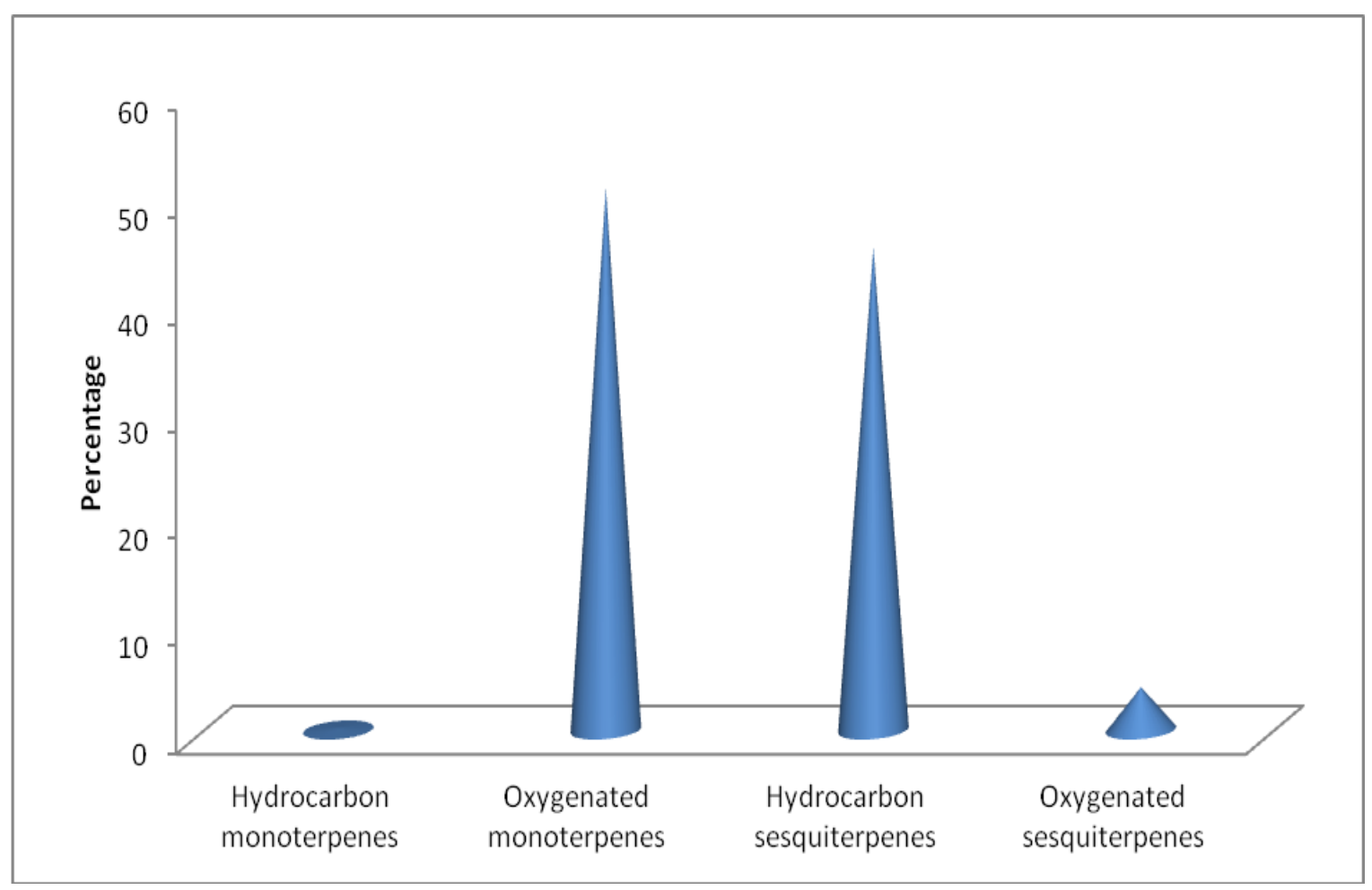

Figure 1:- Terpenoidal composition of the essential oil of $O$. gratissimum

Within the chemical constituents of the essential oil of O. gratissimum, eugenol (41.74\%) was the main constituent followed by caryophellene (21.99\%), isocaryophellene (12.36\%), piperitone (3.43\%) and methyl chavicol (2.74\%).

The present investigated essential oil was characterized by absence of thymol which comprised a major constituent in the essential oil of $O$. gratissimum from many African countries (Asawalam et al., 2008; Benedicta et al., 2012).

Based on the chemotype classification system proposed by Grayer et al. (1996), which is based on the combination of the essential oil major components rather than the sole dominant compound, O. gratissimum under investigation could be classified as eugenol-caryophellene chemotype.

The majority of the of the reported $O$. gratissimum chemotypes, as proposed by Grayer et al. (1996), were eugenol/1,8-cineole ones (Vasconcelos et al., 1999; Silva et al., 2004; Cristiana et al., 2006; Benitez et al., 2009).

The GC/MS analysis of the hydro-distilled $O$. basilicum oil revealed detection and identification of thirty nine compounds (Table 2). 
Table 2:- The chemical composition of the essential oil of $O$. basilicum

\begin{tabular}{|c|c|c|c|}
\hline Peak & $\begin{array}{l}\text { Retention } \\
\text { time }\end{array}$ & Compound & percentage \\
\hline 1 & 10.74 & $\alpha$-pinene & 0.57 \\
\hline 2 & 11.23 & Camphene & 0.10 \\
\hline 3 & 12.09 & $\beta$-phellandrene & 0.52 \\
\hline 4 & 12.18 & $\beta$ - pinene & 1.06 \\
\hline 5 & 12.69 & $\beta$-myrcene & 1.26 \\
\hline 6 & 13.78 & p-cymene & 0.25 \\
\hline 7 & 13.93 & Terpinolene & 0.79 \\
\hline 8 & 14.03 & 1,8-cineole & 5.75 \\
\hline 9 & 14.55 & $\beta$-transocimene & 0.24 \\
\hline 10 & 15.17 & Trans-sabinene hydrate & 0.12 \\
\hline 11 & 15.34 & Epoxy linalool & 0.31 \\
\hline 12 & 15.85 & Fenchone & 0.38 \\
\hline 13 & 16.36 & Linalool & 17.41 \\
\hline 14 & 17.63 & camphor & 0.26 \\
\hline 15 & 18.29 & Myrcenol & 0.29 \\
\hline 16 & 19.07 & $\alpha$-terpineol & 1.21 \\
\hline 17 & 19.40 & Methyl chavicol (estragole) & 39.26 \\
\hline 18 & 19.53 & octylacetate & 0.73 \\
\hline 19 & 20.05 & Nerol & 0.30 \\
\hline 20 & 20.43 & Neral & 0.86 \\
\hline 21 & 20.85 & geraniol & 0.70 \\
\hline 22 & 21.27 & Geranial & 0.94 \\
\hline 23 & 21.73 & Bornyl acetate & 1.36 \\
\hline 24 & 23.72 & m-eugenol & 3.51 \\
\hline 25 & 24.18 & $\alpha$-copaene & 0.45 \\
\hline 26 & 24.60 & $\beta$-elemene & 1.87 \\
\hline 27 & 24.87 & $\beta$-cubebene & 1.18 \\
\hline 28 & 25.36 & Caryophellene & 1.31 \\
\hline 29 & 25.71 & Bergamotene & 3.59 \\
\hline 30 & 25.80 & $\alpha$-guaiene & 0.86 \\
\hline 31 & 26.23 & cadina-3,5-diene & 0.99 \\
\hline 32 & 26.44 & Epibicyclosesquiphellandrene & 0.59 \\
\hline 33 & 26.91 & Germacrene D & 1.64 \\
\hline 34 & 27.50 & $\Delta$-guaiene & 1.65 \\
\hline 35 & 27.71 & $\gamma$-cadinene & 2.45 \\
\hline 36 & 28.28 & $\alpha$-bisabolene & 1.17 \\
\hline 37 & 29.25 & Spathulenol & 0.54 \\
\hline 38 & 30.10 & Cubenol & 0.65 \\
\hline 39 & 30.69 & $\Delta$-Cadinol & 2.58 \\
\hline
\end{tabular}

O. basilicum essential oil consisted mainly of oxygenated monoterpenes (73.63\%) followed by hydrocarbon sesquiterpenes, hydrocarbon monoterpenes and oxygenated sesquiterpenes (Fig. 2). 


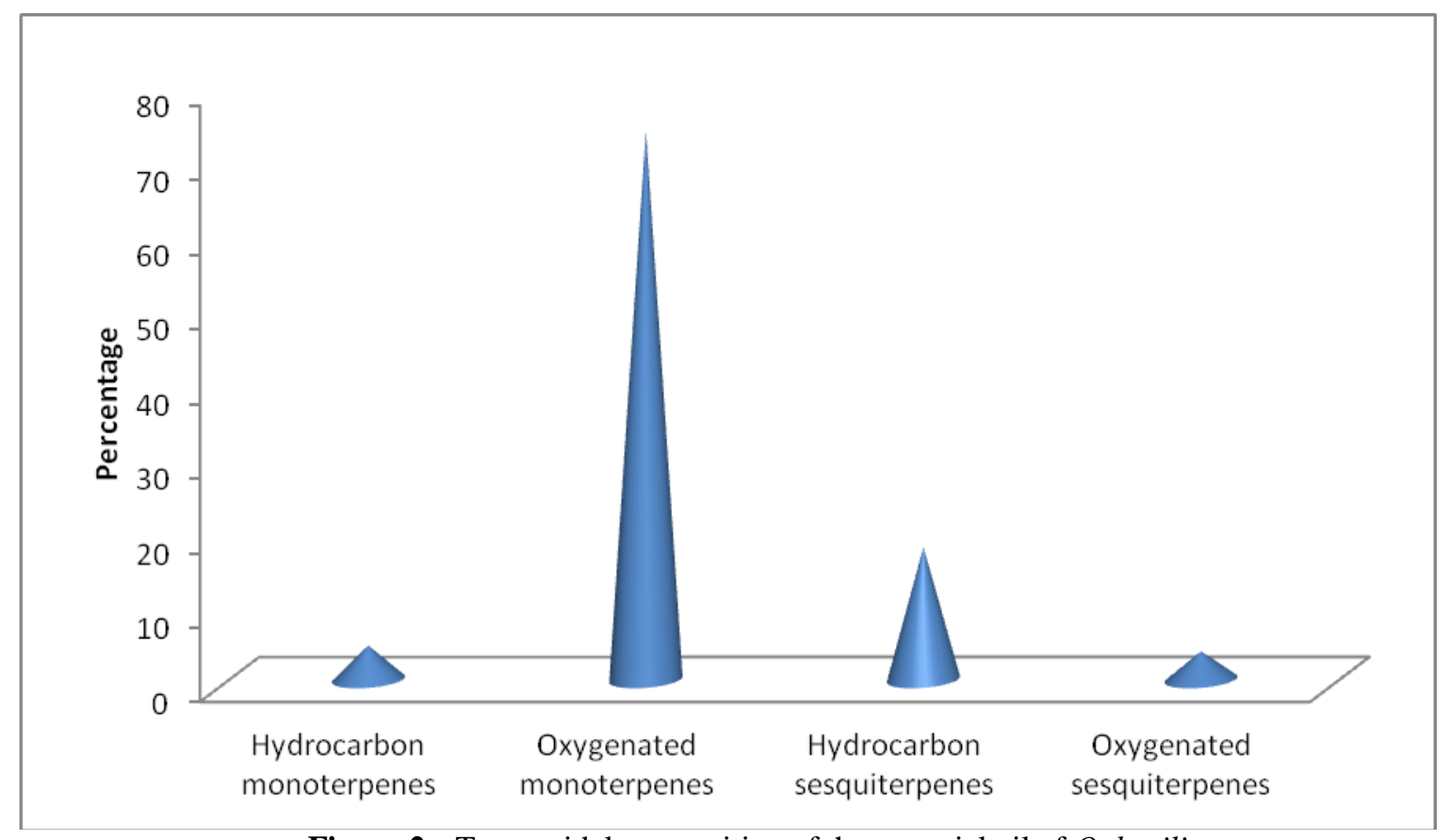

Figure 2:- Terpenoidal composition of the essential oil of $O$. basilicum.

Among the detected monoterpenes, the main constituent identified was methyl chavicol, representing about (39.26\%) of the oil, followed by linalool (17.41\%), 1,8-cineole (5.75\%) and m-eugenol (3.51\%).

The chemistry of the essential oil from leaves of $O$. basilicum in this study is similar to some previously investigated $O$. basilicum essential oil, from different origins, in presence of methyl chavicol as the main constituent (Sajjids, 2006; Bunrathep et al., 2007; Mindaryani and Sri Rahayu, 2007; Vani et al., 2009).

\section{Conclusion:-}

It could be concluded that $O$. gratissimum and $O$. basilicum cultivated in Sudan could be classified as eugenol/caryophellene chemotype and methyl chavicol (estragole) chemotype, respectively.

\section{References:-}

1. Anwar, F., Hussain, A.I., Sherazi, S.T. and Przybylski, R. (2008): Chemical composition, antioxidant and antimicrobial activities of basil (Ocimum basilicum) essential oils depend on seasonal variations. Food Chemistry, 108: 986-995.

2. Asawalam, E.F, Emosairue, S.O. and Hassanali, A. (2008): Essential oil of Ocimum grattissimum (Labiatae) as Sitophilus zeamais (Coleoptera: Curculionidae) Protectant. African Journal of Biotechnology, 7 (20), pp. 37713776.

3. Benitez, N.P, León, E.M.M. and Stashenko, E.E. (2009): Eugenol and Methyl Eugenol Chemotypes of Essential Oil of Species Ocimum gratissimum L. and Ocimum campechianum Mill. from Colombia. Journal of Chromatographic Science, 47: (800-803).

4. Beric-Bjedov, T., Stajkovic, O., Mitic-Culafic, D., Stankovic, S., Vukovic-Gacic, B., Simic, D. and KnezevicVukcevic, J. (2007): Antimutagenic Properties of Basil (Ocimum basilicum L.) in Salmonella typhimurium TA100. Food Technology and Biotechnology, 45 (2): 213-217.

5. Brada, M., Khelifa L.H., Achour, D., Wathelet, J.P. and Lognay, G. (2011): Essential Oil Composition of Ocimum basilicum L. and Ocimum gratissimum L. from Algeria. Journal of Essential Oil Bearing Plants, 14 (6): $810-814$

6. Bunrathep, S., Palanuvej, C. and Ruangrungsi, N. (2007): Chemical Composition and Antioxidative Activities of Essential Oils from Four Ocimum Species Endemic to Thailand. Journal of health Research, 21(3): 201-206.

7. Cristiana, M., Murbach, F., M'arcia, O.M. and Mirtes, C. (2006): Effects of seasonal variation on the central nervous system activity of Ocimum gratissimum L. essential oil. Journal of Ethnopharmacology, 105: 161-6. 
8. Grayer, R.J, Kite, G.C, Goldstone, F.J. and Bryan, S.E., Paton, A., Putievsky, E. (1996): Intraspecific taxonomy and essential oil chemotypes in sweet basil, Ocimum basilicum. Phytochemistry, 43(5): 1033-1039.

9. Holadova, K., Klimankova, E., Hajslova, J., Cajka, T., Poustka, J. and Koudela, M. (2008): Aroma profiles of five basil (Ocimum basilicum L.) cultivars grown under conventional and organic conditions. Food Chemistry, 107: 464-472.

10. Khan, S .A, Al-Abbasy, D.W, Pathare, N. and Al-Sabahi, J.N. (2015): Chemical composition and antibacterial activity of essential oil isolated from Omani basil (Ocimum basilicum Linn.). Asian Pacific Journal of Tropical Disease, 5(8): 645-649.

11. Koba, K., Poutouli, P.W., Raynaud, C., Chaumont, J-P., and Sanda, K. (2009): Chemical composition and antimicrobial properties of different basil essential oils chemotypes from Togo. Bangladesh Journal of Pharmacology, 4: 1-8.

12. Koutsos, T.V., Chatzopoulou, P.S. and Katsiotis, S.T. (2009): Effects of individual selection on agronomical and morphological traits and essential oil of a "Greek basil" population. Euphytica, 170:365-370.

13. Lawrence, B.M. (1988): A further examination of the variation of Ocimum basilicum L. In Lawrence, B.M., Mookerjee, B.D, Willis, B.J. (Eds.). Flavors and Fragrances: A world perspective, Elsevier: 161-170.

14. Matasyoh, L.G, Matasyoh, J.C, Wachira, F.N, Kinyua, M.G., Thairu, A.W. and Mukiama, T.K. (2007): Chemical composition and antimicrobial activity of the essential oil of Ocimum gratissimum L. growing in Eastern Kenya. African Journal of Biotechnology, 6 (6): 760-765

15. Mindaryani, A. and Sri Rahayu, S. (2007): Essential Oil from Extraction and Steam Distillation of Ocimum Basillicum, Proceedings of the World Congress on Engineering and Computer Science, San Francisco, USA.

16. Ozcan, M. and Chalchat, J-C. (2002): Essential Oil Composition of Ocimum basilicum L.

17. and Ocimum minimum L. in Turkey. Czech Journal of Food Sciences, 20 (6): 223-228.

18. Paton, A. (1992): A synopsis of Ocimum L. (Labiatae) in Africa. Kew Bulletin, 47: 405-437.

19. Quetin-Leclercq, J., Benedicta, G.H., Kpoviessi, K., Ladekan, E.Y., Salome, D.S., Gbaguidi, F., Yehouenou, B., Figueredo, G., Moudachirou and M., Accrombessi, G.C. (2012): Chemical Variation of Essential Oil Constituents of Ocimum gratissimum L. from Benin, and Impact on Antimicrobial Properties and Toxicity against Artemia salina Leach. Chemistry and Biodiversity, 9:139-150

20. Saha, S., Dhar, T.N., Sengupta, C. and Ghosh, P.D. (2013): Biological activities of essential oils and methanol extracts of five Ocimum species against pathogenic bacteria. Czech Journal of Food Sciences, 31: 194-202.

21. Sajjids, E. (2006): Analysis of the essential oils of two cultivated basil (Ocimum basilicum L.) from Iran. DARU, 14 (3): 128- 130.

22. Silva, M.G.V., Matos, F.J.A., Lopes, P.R.O, Silva, F.O. and Holanda, M.T. (2004): Composition of essential oils from three Ocimum species obtained by steam and microwave distillation and supercritical $\mathrm{CO} 2$ extraction. ARKIVOC, 6: 66-71.

23. Simon, J.E., Chadwick, A.F. and Craker, L.E. (1984): Herbs: An Indexed Bibliography 1971-1990. Archon Books, Hamden, pp 7-9.

24. Simon, J.E., Quinn, J. and Murray, R.G. (1990): Basil: A score of essential oils. In: Advance in New Crops, Janick J and Simon J E (eds.). Timber press, Portland, Oregong, pp 484-489.

25. Singh, p., Pandey, A.K., Tripathi, N.N. (2014): Chemistry and bioactivities of essential oils of some Ocimum species: an overview. Asian Pacific Journal of Tropical Biomedicine, 4(9): 682-694.

26. Vani, S.R., Cheng, S.F. and Chuah, C.H. (2009): Comparative Study of Volatile Compounds from Genus Ocimum. American Journal of Applied Sciences, 6 (3): 523-528.

27. Vasconcelos, S.M.G., Craveiro, A.A., Abreu, M.F.J, Machado ,M.I.L. and Alencar, J.W. (1999): Chemical variation during daytime of constituents of the essential oil of Ocimum gratissimum leaves. Fitoterapia; 70: 324.

28. Wu, W-J., Li, S-K., Zhang and J-W. (2009): The Main Chemical Composition and in vitro Antifungal Activity of the Essential Oils of Ocimum basilicum Linn. var. pilosum (Willd.) Benth. Molecules, 14:273-278. 